\title{
CRYSTAL STRUCTURE OF (1R,5S)-9-NITRO- 1,2,3,4,5,6-HEXAHYDRO-1,5-METHANOPYRIDO[1,2-a][1,5] DIAZOCIN-8-ONE (9-NITROCYTISINE), $\mathrm{C}_{11} \mathrm{H}_{13} \mathrm{O}_{3} \mathrm{~N}_{3}$
}

\author{
ANTONIO GALDÁMEZ, ${ }^{a} *$ MANUEL GUTIÉRREZ-HERNÁNDEZ, ${ }^{a}$ BRUCE K. CASSELS, ${ }^{a} A N D$ \\ PATRICIO SÁEZ-BRIONES ${ }^{b}$
}

\author{
${ }^{a}$ Departamento de Química, Facultad de Ciencias, Universidad de Chile. Casilla 653, Santiago, Chile \\ ${ }^{b}$ Escuela de Medicina, Facultad de Ciencias Médicas, Universidad de Santiago de Chile, Santiago, Chile
}

(Received: March 18, 2010 - Accepted: April 11, 2011)

\begin{abstract}
The title compound (1, trivial name: 9 (or 3)-nitrocytisine) crystallizes with two independent molecules in the asymmetric unit. In its structure two rings form a bispidine framework that is fused to a 3-nitro-2-pyridone group. The half-normal probability plot reveals that the two molecules do not show any significant geometrical differences, except in conformations of the nitro-group, which is involved in intermolecular interactions. The crystal packing structure of the title compound is described in terms of three-dimensional supramolecular arrays built up from chains of $\mathrm{N}-\mathrm{H} \cdots \mathrm{O}$ (nitro-group), hydrogen bonds and weak intermolecular $\mathrm{C}-\mathrm{H} \cdots \mathrm{O}=\mathrm{C}$ interactions, with graph-set descriptors $C_{2}^{2}(6)$ and $C_{2}^{2}(10)$ motifs, which together result in $R_{4}^{4}(26)$ rings motifs. These chains are additionally stabilized by intermolecular $\mathrm{NO}_{2} \cdots \pi$ interactions.
\end{abstract}

Keywords: crystal structure, X-ray diffraction, cytisinoid

\section{INTRODUCTION}

Cytisine, $\quad(1 R, 5 S)$-1,2,3,4,5,6-hexahydro-1,5-methanopyrido[1,2-a][1,5] diazocin-8-one, is a tricyclic quinolizidine alkaloid found in many plants belonging to the legume family (Fabaceae or Leguminosae). It is of medical interest as an aid to quit smoking, and has been used as such in Eastern Europe for more than forty years. ${ }^{1,2}$ It also served as a template for the design of the anti-smoking drug varenicline (Chantix ${ }^{\circledR}$, Champix $\left.{ }^{\circledR}\right){ }^{3}$ Several pyridonering-substituted derivatives of cytisine have been examined in vitro as nicotinic acetylcholine receptor (nAChR) ligands, ${ }^{4-11}$ and a couple have been subjected to studies in rodents. ${ }^{12-14}$ Most recently the title compound $(1 R, 5 S)$ 9-nitro-1,2,3,4,5,6-hexahydro-1,5-methanopyrido[1,2-a][1,5]diazocin-8one (1, commonly referred to as 9- or 3-nitrocytisine) and its 11 (or 5)-nitro isomer, as well as their 9-bromo-11-nitro- and 11-bromo-9-nitro analogues, have been assayed in vitro vs. nicotinic receptors, and their affinities have been rationalized on the basis of molecular simulation (docking) studies. In particular, 9- (or 3)-nitrocytisine, as compared to varenicline, showed very similar nanomolar affinity for a $4 \mathrm{~b} 2 \mathrm{nAChR}$ and similar high selectivity over the a7 nAChR subtype, but with lower intrinsic efficacy, which might make it an interesting candidate for smoking cessation therapy. ${ }^{15}$

\section{EXPERIMENTAL}

\section{Synthesis}

The nitration of cytisine was first reported in $1894,{ }^{16}$ and the isolation and characterization (but not the structure elucidation) of the title compound were described a few years later. ${ }^{17}$ The latter procedure was followed in general terms in the present work. A cooled solution containing $1.00 \mathrm{~g}(5.26 \mathrm{mmol})$ of cytisine dissolved in $1.5 \mathrm{ml}$ concentrated $\mathrm{H}_{2} \mathrm{SO}_{4}$ was treated dropwise with $1.2 \mathrm{~mL}(19 \mathrm{mmol})$ of concentrated $\mathrm{HNO}_{3}$ and left at room temperature for $5 \mathrm{~h}$. The mixture was cooled again $\left(0^{\circ} \mathrm{C}\right)$ and the reaction was stopped by adding $\mathrm{NH}_{4} \mathrm{OH}$ to adjust the $\mathrm{pH}$ to $9-10$, followed by a standard extraction procedure with $\mathrm{CH}_{2} \mathrm{Cl}_{2}$. The organic phase was dried with anhydrous $\mathrm{Na}_{2} \mathrm{SO}_{4}$ and solvents were removed under reduced pressure. The residue obtained was dissolved in $2.5 \mathrm{ml}$ concentrated $\mathrm{HCl}$, heated under reflux for 15 minutes and the solution neutralized by adding concentrated aqueous $\mathrm{NH}_{3}$. A mixture of 9- and 11-nitrocytisines was obtained after extracting with $\mathrm{CH}_{2} \mathrm{Cl}_{2}$. Finally, the mixture was fractionated using silica gel column chromatography (silica gel 60 Merck; mobile phase: conc. aq. $\mathrm{NH}_{3} / \mathrm{MeOH} / \mathrm{CH}_{2} \mathrm{Cl}_{2}, 1: 10: 89$ ). The final isolated yields were $66 \%$ for 9-nitrocytisine (1) and $2 \%$ for 11-nitrocytisine. The ${ }^{1} \mathrm{H}$ NMR spectra of both products were in agreement with those already published. ${ }^{18}$ The title compound was crystallized in acetone.

\section{Structure determination}

The collection of the intensity data was carried out with the SMART program. ${ }^{19}$ Cell refinement and data reduction were done using SAINT. ${ }^{19}$ The
SHELXL package of crystallographic programs was used to solve and refine the structure ${ }^{20} \mathrm{~A}$ riding model was applied to $\mathrm{H}$ atoms, which were calculated geometrically $(\mathrm{C}-\mathrm{H}: 0.93-0.98)$ and refined with $\mathrm{U}_{\mathrm{isc}}(\mathrm{H})$ values of $1.2 \mathrm{U}_{\mathrm{eq}}(\mathrm{C}) . \mathrm{H}$ atoms of $\mathrm{C} 1, \mathrm{C} 11$ and $\mathrm{N} 3$ were found in difference Fourier maps and refined freely. The molecular graphics used to prepare material for publication were drawn using DIAMOND and PLATON. ${ }^{21,22}$ The crystal data are summarized in Table 1 .

\section{RESULTS AND DISCUSSION}

9-Nitrocytisine (1) crystallizes with two crystallographically independent but conformationally almost identical molecules in the asymmetric unit (Figure1). The molecule consists of three fused rings; a six-membered ring $\mathbf{A}$ in a near-chair conformation fused to a six-membered ring $\mathbf{B}$ in an envelope conformation, which in turn is condensed to the nitropyridone group ring $\mathbf{C}$. Selected bond lengths and angles with their estimated standard deviations (esd's) are given in Table 2. Bond lengths, bond angles and torsion angles in the asymmetric unit of 9-nitrocytisine (1) closely approximate the mean geometry describing the molecular structure of structurally related compounds: (-)-cytisine, (-)- $N$-methylcytisine, $N$-cyanomethylcytisine and $N$-acetonylcytisine..$^{23-25}$

Table 1. Crystal data and details of the structure determination for compound (1).

\begin{tabular}{|c|c|}
\hline \multicolumn{2}{|l|}{ Crystal data } \\
\hline $\mathrm{C}_{11} \mathrm{H}_{13} \mathrm{O}_{3} \mathrm{~N}_{3}$ & $\mathrm{~V}=1039.1(4) \AA^{3}$ \\
\hline$M r=235.24$ & $Z=4$ \\
\hline Monoclinic, $\mathrm{P} 2_{1}$ (No. 4) & Mo $K \alpha$ radiation \\
\hline $\mathrm{a}=10.846(2) \AA$ & $\mu=0.112 \mathrm{~mm}^{-1}$ \\
\hline $\mathrm{b}=6.7227(13) \AA$ & $\mathrm{T}=293 \mathrm{~K}$ \\
\hline $\mathrm{c}=14.295(3) \AA$ & yellow block, $0.1 \times 0.08 \times 0.4 \mathrm{~mm}$ \\
\hline
\end{tabular}

$\beta=94.53(3)^{\circ}$

Data collections

Bruker AXS SMART CCD diffractometer

7461 measured reflections

3466 independent reflections

2605 reflections with $I>2 \sigma(I)$ $\mathrm{R}_{\text {int }}=0.032$

Refinement

$\mathrm{R}\left[\left(F^{2}>2 \sigma\left(F^{2}\right)\right]=0.0501\right.$

$w \mathrm{R}\left(F^{2}\right)=0.0949$

$S=1.01$

3466 reflections

331 parameters

Flack's parameter $=0.000$

$\Delta \rho_{\max }=0.14 \mathrm{e}^{\circ}{ }^{-3}$

$\Delta \rho_{\operatorname{mim}}=-0.16 \mathrm{e}^{\circ}-3$ 


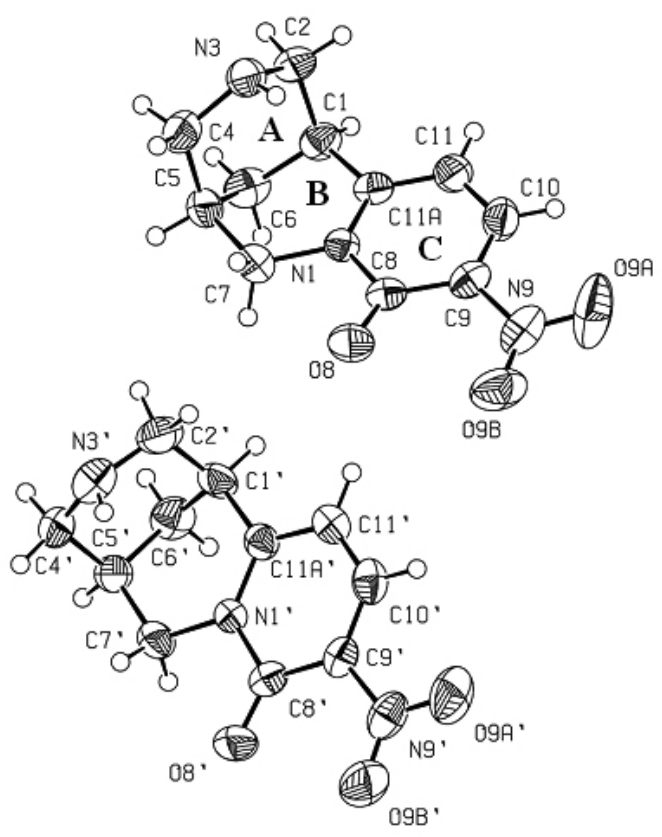

Figure 1. A view of the asymmetric unit of 9-nitrocytisine (1), showing the two independent molecules and atom numbering scheme. Displacement ellipsoids are drawn at the $50 \%$ probability level and $\mathrm{H}$ atoms are shown as small spheres of arbitrary radii.

A comparison of the bond distances and angles of the fitted residues, using a half-normal probability analysis, reveals that the two molecules do not show any significant geometrical differences (see Table 2) ${ }^{26}$ The slope plot of the bond distances is 1.1874 and the intercept is 0.0377 . The largest difference $(0.0130 \AA)$ is between the N1-C11A bond in the first molecule and N1'-C11A' in the second molecule $(2.2981 \Delta / \sigma)$. The main difference between the two molecules lies in the conformations of the nitro-group, which is involved in intermolecular hydrogen bonding (see below), and the differences can thus be ascribed to crystal-packing effects. As a result, the dihedral O9A-N9-C9-C10 torsion angle of the nitro-group in the first molecule is $7.1(5)^{\circ}$ (view table 2). The nitro-group in the second molecule presents a coplanar configuration with respect to the main plane of the molecule $\left[\mathrm{O}^{\prime} \mathrm{A}^{\prime}-\mathrm{N}^{\prime}-\mathrm{C}^{\prime}-\mathrm{C} 10^{\prime}=0.4(5)^{\circ}\right]$. The mean N-O bond lengths are in the usual range [1.214(5)-1.226(5) $\AA]$ for aromatic nitro-groups.

Ring A (N3/C1-C6) adopts a near-chair conformation as indicated by the Cremer and Pople puckering parameters, having a total puckering amplitude QT of $0.573(3) \AA$ and near-chair conformation with $\varphi=170.6(15)^{\circ}$ and $\theta=$ $13.0(3)^{\circ}{ }^{\circ 7}$ The $\mathrm{N} 3, \mathrm{C} 2, \mathrm{C} 4$ and $\mathrm{H} 3$ atoms form a distorted pyramid with $s p^{3}$ hybridization of the central nitrogen atom, with the sum of the three angles amounting to $334.8^{\circ}$ (Figure 1). Ring B (C1/C11a/N1/C5-C7) adopts an envelope conformation, having a total puckering amplitude QT of $0.551(3)$ $\AA\left[\varphi=169.5(4)^{\circ}\right.$ and $\left.\theta=52.3(3)^{\circ}\right]$. A similar geometry is observed in (-)-cytisine. ${ }^{23}$ The C11a-C1-C2 bond angle in $\mathbf{1}$ is $109.6(3)^{\circ}$ and $\mathrm{N} 1$ adopts a planar configuration $\left[\mathrm{C} 11 \mathrm{a}-\mathrm{N} 1-\mathrm{C} 7=123.1(2)^{\circ}\right]$. The sum of the three angles about atom $\mathrm{N}_{1}$ reflects $s p^{2}$ geometry (table 2$)$. The pyridone ring $\mathrm{C}(\mathrm{N} 1 / \mathrm{C} 11 \mathrm{~A} /$ C8-C11) in $\mathbf{1}$ is essentially planar (Figure 1).

Table 2. Selected geometric parameters: bond lengths $[\AA]$, torsion angles and bond angles $\left[{ }^{\circ}\right]$.

\begin{tabular}{|c|c|c|c|}
\hline & & & \\
\hline C8-C9 & $1.432(4)$ & C7-N1-C11a & $123.1(2)$ \\
\hline C8'-C9' & $1.431(5)$ & C8-N1-C11a & $124.1(2)$ \\
\hline C5-C6 & $1.514(4)$ & C7-N1-C8 & $112.8(2)$ \\
\hline C5'-C6' & $1.510(4)$ & O9A-N9-O9B & $121.8(3)$ \\
\hline N3-C4 & $1.448(4)$ & O9A'-N9'-O9B' & $121.6(3)$ \\
\hline N3'-C4' & $1.442(5)$ & O9B'-N9'-C9'-C10' & $-179.0(3)$ \\
\hline N9-C9 & $1.437(5)$ & O9B-N9-C9-C10 & $-172.1(3)$ \\
\hline
\end{tabular}

The two independent molecules in $\mathbf{1}$ form intermolecular interactions. $\mathrm{N}-\mathrm{H} \cdots \mathrm{O}$ (nitro-group) hydrogen bonds and weak intermolecular $\mathrm{C}-\mathrm{H} \cdots \mathrm{O}=\mathrm{C}$ interactions (Table 1) link the molecules, with together are effective in the stabilization of the structure. The crystal packing structure contains chains that run along the crystallographic $b$-axis, generated by the classical $\mathrm{N}-\mathrm{H} \cdots \mathrm{O}$ hydrogen bonds forming a graph-set descriptor $C_{2}^{2}(10)$ motif (Figure 2) ${ }^{28-29}$ The overall effect is that the N3-H3 $\cdots \mathrm{O}^{\prime} \mathrm{B}^{\prime}[-\mathrm{x}+1, \mathrm{y}-1 / 2,-\mathrm{z}+1]$ and $\mathrm{N} 3{ }^{\prime}-$ $\mathrm{H} 3^{\prime} \cdots \mathrm{O} 9 \mathrm{~B}[-\mathrm{x}+1, \mathrm{y}-1 / 2,-\mathrm{z}+1]$ interactions form an infinite one-dimensional chain zigzagging parallel to the [010] plane (table 3 and figure 2). The intermolecular $\mathrm{C} 11-\mathrm{H} 11 \cdots \mathrm{O} 8^{\prime}[\mathrm{x}, \mathrm{y}, \mathrm{z}+1]$ and $\mathrm{C}^{\prime}-\mathrm{H} 1^{\prime} \cdots \mathrm{O} 8[\mathrm{x}, \mathrm{y}, \mathrm{z}]$ interactions form a graph-set descriptor $C_{2}^{2}(10)$ motif as viewed along the $c$-axis, with $\mathrm{H}$-acceptor distances which are less than the sum of the van der Waals radii (table 3 and figure 2). ${ }^{30-31}$ The combination of these two interactions $(\mathrm{N}-\mathrm{H} \cdots \mathrm{O}$ and $\mathrm{C}-\mathrm{H} \cdots \mathrm{O}=\mathrm{C}$ ) produces two types of $R_{4}^{4}(26)$ ring motifs (Figure 3). The first motif is formed by of $\mathrm{N} 3-\mathrm{H} 3 \cdots \mathrm{O}$ - $\mathrm{B}$ hydrogen bonds and $\mathrm{C} 11-\mathrm{H} 11 \cdots \mathrm{O} 8^{\prime}$ $[\mathrm{x}, \mathrm{y}, \mathrm{z}+1]$ interactions. The second motif is the formation of $\mathrm{N} 3-\mathrm{H} 3 \cdots \mathrm{O} 9 \mathrm{~B}$ and $\mathrm{C} 1^{\prime}-\mathrm{H} 1^{\prime} \cdots \mathrm{O} 8[\mathrm{x}, \mathrm{y}, \mathrm{z}]$ interactions. The supramolecular structure is additionally stabilized by intermolecular $\mathrm{NO}_{2} \cdots \pi$ interactions, ${ }^{32-33}$ with connect the $\mathrm{Cg}$ centroids of the $\mathrm{N} 1 / \mathrm{C} 11 \mathrm{~A} / \mathrm{C} 8-\mathrm{C} 11$ rings with the $\mathrm{O} 9 \mathrm{~B}$ atoms of the nitro group (Figure 3 and table 3).

Table 3. Hydrogen-bond and intermolecular contact interaction geometry $\left(\AA,{ }^{\circ}\right)$.

\begin{tabular}{|c|c|c|c|c|}
\hline $\mathrm{D}-\mathrm{X} \ldots \mathrm{A}$ & $d(D-X)$ & $d(X \ldots A)$ & d(D...A) & $<(\mathrm{DXA})$ \\
\hline N3-H3 $\cdots \mathrm{O}^{\prime} \mathrm{B}^{\prime \mathrm{iii}}$ & $0.85(3)$ & $2.53(3)$ & $3.362(4)$ & $165(3)$ \\
\hline $\mathrm{N} 3^{\prime}-\mathrm{H}^{\prime} \cdots \mathrm{O}^{\prime} \mathrm{B}^{\mathrm{iii}}$ & $0.82(3)$ & $2.57(3)$ & $3.284(4)$ & $147(3)$ \\
\hline $\mathrm{C} 11-\mathrm{H} 11 \cdots \mathrm{O}^{\prime \mathrm{i}}$ & $0.93(3)$ & $2.46(3)$ & $3.315(4)$ & $153(2)$ \\
\hline $\mathrm{C} 1^{\prime}-\mathrm{H} 1^{\prime} \cdots \mathrm{O} 8^{\mathrm{ii}}$ & $0.96(3)$ & $2.38(3)$ & $3.241(4)$ & $150(2)$ \\
\hline N9'-O9B' $\cdots \mathrm{Cg} 1^{\text {iii }}$ & $1.217(4)$ & $3.347(3)$ & $3.395(3)$ & $81.83(18)$ \\
\hline N9'-O9B' $\cdots \mathrm{Cg} 1^{\text {iv }}$ & $1.217(4)$ & $3.498(3)$ & $4.130(3)$ & $113.1(2)$ \\
\hline $\mathrm{N} 9-\mathrm{O} 9 \mathrm{~B} \cdots \mathrm{Cg} 2^{\text {iv }}$ & $1.214(5)$ & $3.270(4)$ & $3.596(4)$ & $95.5(2)$ \\
\hline
\end{tabular}

Symmetry code : (i) $\mathrm{x}, \mathrm{y}, 1+\mathrm{z}$, (ii) $\mathrm{x}, \mathrm{y}, \mathrm{z}$, (iii) $1-\mathrm{x},-1 / 2+\mathrm{y}, 1-\mathrm{z}$, (iv) $1-\mathrm{x}, 1 / 2+\mathrm{y}, 1-\mathrm{z}$

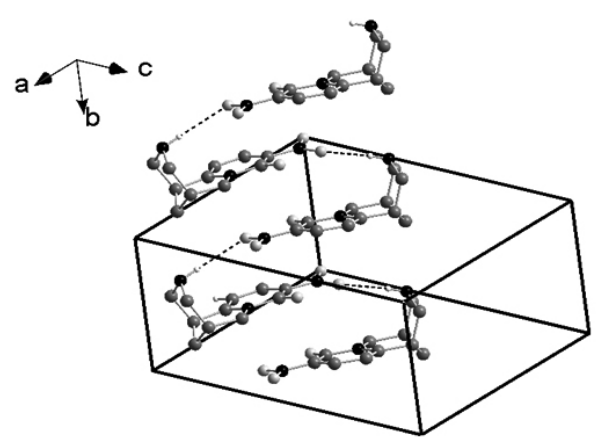

$\mathrm{a}$

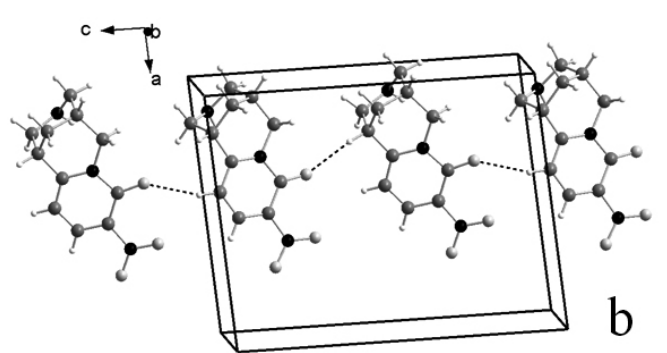

Figure 2. A partial packing view of 9-nitrocytisine: (a) view of the $\mathrm{N}-\mathrm{H} \cdots \mathrm{O}$ hydrogen bonds and the formation of a $C_{2}^{2}(10)$ chain parallel to [010] and (b) The intermolecular $\mathrm{C}-\mathrm{H} \cdots \mathrm{O}=\mathrm{C}$ interaction and formation of a $C_{2}^{2}(6)$ chain running along the $c$-axis. Dashed lines represent intermolecular interactions and $\mathrm{H}$ atoms not involved in hydrogen bonds have been omitted for clarity. 

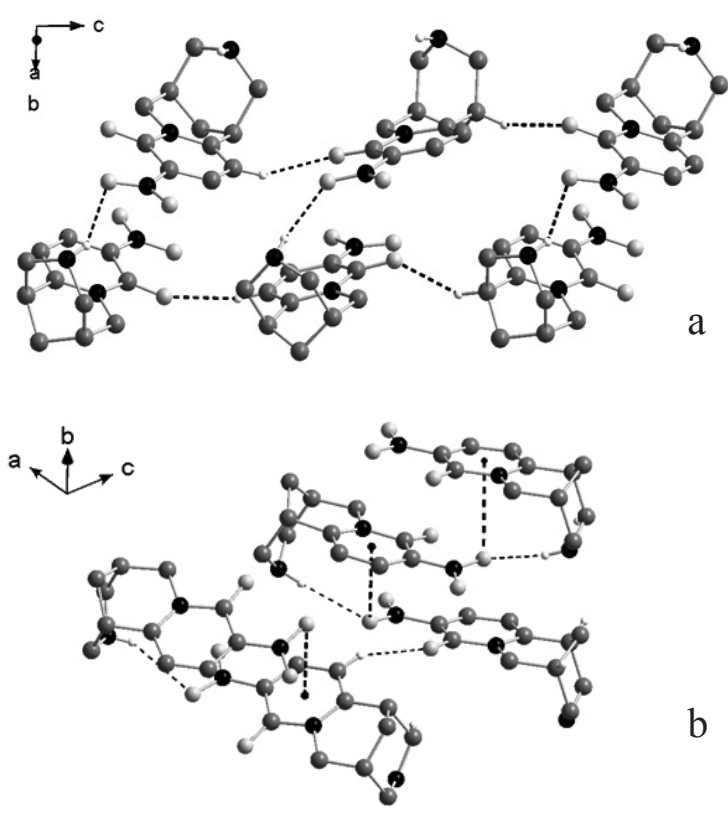

$\mathrm{b}$

Figure 3. A partial packing view of 9-nitrocytisine showing: (a) the formation of intermolecular interactions $(\mathrm{C}-\mathrm{H} \cdots \mathrm{O}=\mathrm{C}$ and $\mathrm{N}-\mathrm{H} \cdots \mathrm{O})$ of $R_{4}^{4}(26)$ rings in the $b c$ plane and (b) nitro-group $\cdots$ p interactions. The centroids $\mathrm{Cg}$ are denoted by small black spheres. Dashed lines represent intermolecular interactions and $\mathrm{H}$ atoms not involved in intermolecular interactions have been omitted for clarity.

\section{ACKNOWLEDGMENTS}

M. T. Garland and A. Ibáñez are thanked for the X-ray measurements and FONDAP Grant N ${ }^{\circ} 11980002$ for the purchase of the Bruker SMART CCD single crystal diffractometer. The synthetic work was funded by FONDECYT and ICM grants $\mathrm{N}^{\circ} 1040776$ and P-05-001-F, respectively.

Supplementary Information: Crystallographic data (excluding structure factors) for the structural analysis have been deposited in the Cambridge Crystallographic Data Centre CCDC 763441. Data Acquisition - the Cambridge Crystallographic Data Centre deposit@ccdc.cam.ac.uk Telephone: (44) 01223 762910 Facsimile: (44) 01223336033 Postal Address: CCDC, 12 Union Road, CAMBRIDGE CB2 1EZ, UK (http://www.ccdc.cam.ac.uk/).

\section{REFERENCES}

1.- P. Tutka, W. Zatoński, Pharmacol. Rep. 58, 777 (2005).

2.- J.F. Etter, R.J. Lukas, N.L. Benowitz, R. West, C.M. Dresler, Drug Alcohol Depend. 92, 3 (2008).

3.- J.W. Coe, P.R. Brooks, M.G. Vetelino, M.C. Wirtz, E.P. Arnold, J. Huang, S.B. Sands, T.I. Davis, L.A. Lebel, C.B. Fox, A. Shrikhande, J.H. Heym, E. Schaeffer, H. Rollema, Y. Lu, R.S: Mansbach, L.K. Chambers, C.C. Rovetti, D.W. Schulz, F.D. Tingley 3rd, B.T. O'Neill, J. Med. Chem. 48, 3474 (2005).

4.- P. Imming, P. Klaperski, M.T. Stubbs, G. Seitz, D. Gündisch, Eur. J. Med. Chem. 36, 375 (2001).

5.- $\quad$ L.M. Houlihan, Y. Slater, D.L. Guerra, J.-H. Peng, Y.-P. Kuo, R.J. Lukas, B.K. Cassels, I. Bermudez, J. Neurochem. 78, 1029 (2001).

6.- Y.E. Slater, L.M. Houlihan, P.D. Maskell, R. Exley, I. Bermúdez, R.J. Lukas, A.C. Valdivia, B.K. Cassels, Neuropharmacology 44, 503 (2003).

7.- R.W. Fitch, Y. Kaneko, P. Klaperski, J.W. Daly, G. Seitz, D. Gündisch, Bioorg. Med. Chem. Lett. 15, 1221 (2005).

8.- B.K. Cassels, I. Bermúdez, F. Dajas, J.A. Abin-Carriquiry, S. Wonnacott, Drug Discov. Today 10, 1657 (2005).

9.- R. Varas, V. Valdés, P. Iturriaga-Vásquez, B.K. Cassels, J. Alcayaga, R. Iturriaga, Brain Res. 1072, 72 (2006).

10.- J.A. Abin-Carriquiry, M.H. Voutilainen, J. Barik, B.K. Cassels, P. Iturriaga-Vásquez, I. Bermúdez, C. Durand, F. Dajas, S. Wonnacott, Eur. J. Pharmacol., 536, 1 (2006).
11.- M. Moroni, R. Zwart, E. Sher, B.K. Cassels, I. Bermudez, Mol. Pharmacol. 70, 755 (2006)

12.- J.A. Abin-Carriquiry, G. Costa, J. Urbanavicius, B.K. Cassels, M. Rebolledo-Fuentes, S. Wonnacott, F. Dajas, Eur. J. Pharmacol. 589, 80 (2008).

13.- C.A. Zambrano, M.J. Marks, B.K. Cassels, R.B. Maccioni, Neuropharmacology 57, 332 (2009).

14.- Y.S. Mineur, C. Eibl, G. Young, C. Kochevar, R.L. Papke, D. Gündisch, M.R. Picciotto, J. Pharmacol. Exp. Ther. 329, 377 (2009).

15.- P. Sáez-Briones, M. Rebolledo-Fuentes, A. Carbone, M. Moroni, G. Zapata-Torres, M. Gutiérrez-Hernández, P.C. Biggin, B.K. Cassels, I. Bermúdez, manuscript in preparation.

16.- A. Partheil, Arch. Pharm. 232, 161 (1894).

17.- M. Freund, A. Friedmann, Ber. dtsch. chem. Ges. 34, 605 (1901)

18.- E. Marrière, J. Rouden, V. Tadino, M.C. Lasne, Org. Lett. 2, 1121 (2000).

19.- SMART, SAINTPLUS V6.02, SHELXTL V6.10 and SADABS; Bruker Analytical X-ray Instruments Inc., Madison, Wisconsin, USA.

20.- G.M. Sheldrick, 1997. SHELXL-97. Program for the Refinement of Crystal Structures. University of Göttingen, Germany.

21.- K. Brandenburg, DIAMOND. Visual Crystal Structure Information System. Version 2.1e Crystal Impact GbR, Bonn, Germany 1999.

22.- PLATON Program: A.L. Spek, J. Appl. Cryst. 36, 7-13 (2003).

23.- P.B. Wakchaure, S. Easwar, V.G. Puranik, N.P. Argade, Tetrahedron, 64, $1786(2008)$.

24.- O.A. Nurkenov, A.M. Gazaliev, K.M. Turdybekov, A.B. Shalbaeva, A. Aubakirova, M.Zh. Zhurinov, Zh. Obshch. Khim. (Russ.) (Russ. J. Gen. Chem.) 69, 675 (1999).

25.- O.A. Nurkenov, A.M.Gazaliev, K.M. Turdybekov,A.B. Bukeeva, I.V. Kulakov, Zh. Obshch. Khim. (Russ.) (Russ. J. Gen. Chem. ,73, 1015 (2003).

26.- S.C. Abrahams, E.T. Keve, Acta Cryst. A27, 157 (1971).

27.- D. Cremer, J.A. Pople, J. Am. Chem. Soc. 97, 1354 (1975).

28.- J. Bernstein, R.E. Davis, L. Shimoni, N.-L. Chang, Angew. Chem.Int. Ed. Engl. 34, 1555 (1995).

29.- M. Etter, Acc. Chem. Res., 23,120 (1990)

30.- G.R. Desiraju, Acc. Chem. Res., 24 ,290 (1991)

31.- G.R. Desiraju, Acc. Chem. Res. 29, 441 (1996).

32.- B.R. Kaafarani, B. Wex, A.G. Oliver, J.A. Krause Bauer, D.C. Neckers, Acta Cryst. E59, o227 (2003).

33.- K. Kubo, E. Yamamoto, A. Mori. Acta Cryst. C57, 611 (2001). 